\title{
HUBUNGAN ANTARA KEKUATAN OTOT TUNGKAI, KEKUATAN \\ OTOT PERUT, DAN KOORDINASI MATA TANGAN DENGAN \\ KEMAMPUAN TOLAK PELURU GAYA O'BRIEN PADA \\ SISWA PUTRI KELAS XII SMK TRI SAKTI \\ GEMOLONG TAHUN 2019.
}

\author{
Oleh Iwan Arya Kusuma
}

\begin{abstract}
ABSTRAK
Tujuan dari penelitian ini adalah untuk mengetahui: (1) Hubungan antara Kekuatan Otot TungkaiDengan Kemampuan Tolak Peluru Gaya O'BrienPada Siswa Putri Kelas XII SMKTri Sakti GemolongTahun 2019.(2) Hubungan antara Kekuatan Otot Perut Dengan Kemampuan Tolak Peluru Gaya O'BrienPada Siswa Putri Kelas XII SMKTri Sakti GemolongTahun 2019. (3) Hubungan antara Koordinasi Mata Tangan Dengan Kemampuan Tolak Peluru Gaya O'BrienPada Siswa Putri Kelas XII SMKTri Sakti GemolongTahun 2019 (4) Hubungan antara Kekuatan Otot Tungkai, Kekuatan Otot Perut, Dan Koordinasi Mata Tangan Dengan Kemampuan Tolak Peluru Gaya O’BrienPada Siswa Putri Kelas XII SMKTri Sakti GemolongTahun 2019.

Sesuai dengan tujuan penelitian ini, maka penelitian ini menggunakan metode deskriptif dengan pendekatan studi korelasional. penelitian ini dilaksanakan pada bulan Nopember tahun 2018. Dalam penelitian ini variabel bebas disebut juga sebagai prediktor dan variabel terikat yang disebut juga sebagai kriterium. Teknik pengumpulan data dalam penelitian ini adalah menggunakan teknik tes dan pengukuran. Adapun jenis tes yang digunakan adalah: (1)Tes dan pengukuran kekuatan otot tungkai dengan leg dynamometer(Johnson \& Nelson, 1986: 210). (2) Tes dan pengukuran kekuatan otot perut dengan sit-up test (Nurhasan,2001:141). (3) Tes dan pengukuran koordinasi mata tangan dengantes lempar tangkap bola tenis (Kirkendall, et al, 1987: 412). (4) Tes dan pengukuran tolak peluru gaya O'Brien menggunakan petunjuk pelaksanaan testolak peluru gaya $O$ 'Brien (Persatuan Atletik Seluruh Indonesia, 1996: 142).

Berdasarkan analisis data dan pengujian hipotesis, maka simpulan yang dapat diperoleh adalah: (1) Ada hubungan yang signifikanantara Kekuatan Otot Tungkai dengan Tolak Peluru Gaya O'Brien, $\mathrm{r}_{\text {hitung }}=0.411>\mathrm{r}_{\text {tabel }} \%=0,361$. (2) Ada hubungan yang signifikan antara Kekuatan Otot Perut dengan Tolak Peluru Gaya O'Brien, $\mathrm{r}_{\text {hitung }}=0.433>\mathrm{r}_{\text {tabel }} 5 \%=0,361$. (3) Ada hubungan yang signifikan antara Koordinasi Mata Tangan dengan Tolak Peluru Gaya O'Brien, $\mathrm{r}_{\text {hitung }}=0.480$ $>\mathrm{r}_{\text {tabel }} 5 \%=0,361$. (4) Ada hubungan yang signifikan antara Kekuatan Otot Tungkai, Kekuatan Otot Perutdan Koordinasi Mata Tangan dengan Tolak Peluru

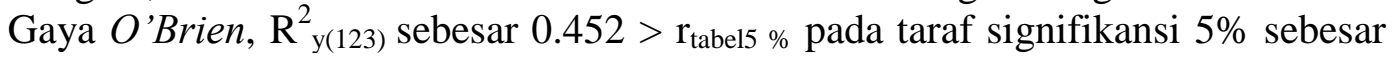
0.361 dan $F_{0}$ sebesar $6.6541>f_{\text {tabel }}$ pada taraf signifikansi $5 \%$ sebesar 2,89.
\end{abstract}

Kata Kunci : Kekuatan Otot Tungkai, Kekuatan Otot Perut, Koordinasi Mata Tangan, Tolak Peluru Gaya O’Brien. 


\section{Hubungan Antara Kekuatan Otot Tungkai, Kekuatan Otot Perut, Dan Koordinasi Mata Tangan Dengan Kemampuan Tolak Peluru Gaya O’brien Pada Siswa Putri Kelas XII SMK Tri Sakti Gemolong Tahun 2019 (Iwan Arya Kusunma)}

\section{A. PENDAhuluan}

Atletik merupakan olahraga yang mempunyai karakteristik olahraga berat, karena seorang atlet atletik harus mempunyai kemampuan fisik yang luar biasa jika ingin berprestasi. Cabang olahraga atletik dapat dikatakan sebagai dasar gerak kemampuan dasar, seperti gerak berlari, melompat, dan melempar. Dalam perkembangannya olahraga atletikpun telah merambah ke dalam dunia pendidikan, khususnya diajarkan dalam mata pelajaran penjasorkes di sekolahsekolah. Baik dari tingkat Sekolah Dasar, SMP, maupun SMA semuanya wajib memasukkan nomor olahraga atletik kedalam kegiatan belajarnya. Masuknya cabang olahraga atletik ke dalam pendidikan jasmani diharapkan siswa dapat memiliki kebugaran fisik yang baik, serta mampu memberikan kecerdasan dari sisi psikomotor.

Manusia dalam melakukan aktivitas sehari-hari memerlukan kondisi jasmani yang baik. Tingkat kesegaran jasmani seseorang akan berpengaruh terhadap kesiapan fisik maupun pikiran untuk sanggup menerima beban kerja. Hal ini juga berlaku bagi siswa, dimana seorang siswa mempunyai tugas belajar. Tugas belajar tersebut akan dapat dilaksanakan dengan baik apabila siswa mempunyai tingkat kesegaran jasmani yang baik.

Dalam implementasi dalam mengajarkan sejumlah kegiatan pembelajaran merupakan upaya pokok dalam mewujudkan pendidikan jasmani di dalam mencapai tujuannya. Memilih dan menetapkan berbagai kegiatan mengajar dan kegiatan belajar merupakan garapan dan strategi pembelajaran. Strategi pembelajaran yang baik akan menghasilkan proses belajar yang lebih menekankan pada pengalaman gerak, pertumbuhan, perkembangan dan pembinaan mental anak. Untuk dapat memenuhi kebutuhan-kebutuhan tersebut diperlukan metode praktek yang tepat dan terarah. Hal terpenting dalam pendidikan jasmani adalah praktek menguasai gerakan yang dipelajarinya. Praktek merupakan kondisi internal yang penting dalam usahanya untuk menguasai keterampilan gerakan. Keterampilan dapat dicapai secara bertahap melalui praktek yang dilakukan secara berulang-ulang. Pengaruh praktek yang dilakukan secara berulang-ulang akan tampak pada pelaksanaan gerakan yang semakin mulus, lancar dan semakin 


\section{Hubungan Antara Kekuatan Otot Tungkai, Kekuatan Otot Perut, Dan Koordinasi Mata Tangan Dengan Kemampuan Tolak Peluru Gaya O’brien Pada Siswa Putri Kelas XII SMK Tri Sakti Gemolong Tahun 2019 (Iwan Arya Kusunma)}

berkurangnya kesalahan-kesalahan yang dilakukan serta lebih sering penampilan terbaiknya dapat dicapai, dengan demikian akan terjadi otomatisasi gerak.

Di dalam melakukan kegiatan olahraga haruslah dapat mengatur antara kegiatan, istirahat dan menu makanan yang sesuai, agar kegiatan olahraga yang dijalankan dapat memperoleh hasil sesuai yang diinginkan. Olahraga dapat dijadikan sebagai alat pemersatu bangsa, misalnya dengan melakukan pertandingan persahabatan dari tidak kenal menjadi kenal, saling mengunjungi satu sama lain yang akhirnya timbullah rasa persaudaraan walaupun tidak ada hubungan keluarga.

Olahraga saat ini dapat dijadikan sarana untuk mencari uang, sudah barang tentu olahraga tersebut adalah olahraga prestasi. Seperti diketahui banyak lapangan pekerjaan bagi atlet-atlet yang berprestasi. Sebetulnya tidak susah dalam memperoleh atlet-atlet yang berbakat dan berprestasi karena bangsa Indonesia mempunyai jumlah penduduk yang begitu banyak dan tersebar di tiga puluh tiga propinsi. Selain itu bangsa Indonesia mempunyai semangat yang tidak diragukan lagi, terbukti adanya kemerdekaan yang dinikmati sekarang ini. Prestasi yang dimiliki seorang atlet semata-mata bukan miliknya sendiri akan tetapi dapat juga mengharumkan nama bangsa dan negara yang ia tempati, selain juga dapat menimbulkan rasa bangga bagi orang lain, serta dapat menumbuhkan rasa persatuan yang kuat bagi orang lain. Tujuan lain dari pendidikan olahraga adalah merupakan salah satu wadah untuk mendapatkan bibit atlet yang berbakat dan berprestasi yang nantinya dapat mengharumkan nama bangsa dan negara di mata dunia.

Latihan fisik pada setiap cabang olahraga merupakan pondasi utama dalam pembinaan ekstrakurikuler. Semua komponen biomotor harus dapat dikembangkan untuk menunjang prestasi siswa. Dengan modal fisik yang prima tentunya siswa akan dapat menguasai tahap latihan selanjutnya. Siswa Putri SMK Tri Sakti Gemolong sudah bisa melakukan tolak peluru gaya o'brien. Ekstrakurikuler tolak peluru dilakukan selama tiga kali dalam satu minggu, dan duabelas kali dalam satu bulan. Selama ini pada praktik mata pelajaran olahraga, latihan yang diberikan lebih menekankan pada faktor teknik. Sedangkan kondisi 


\section{Hubungan Antara Kekuatan Otot Tungkai, Kekuatan Otot Perut, Dan Koordinasi Mata Tangan Dengan Kemampuan Tolak Peluru Gaya O’brien Pada Siswa Putri Kelas XII SMK Tri Sakti Gemolong Tahun 2019 (Iwan Arya Kusunma)}

fisik belum dibina secara maksimal, hal ini bisa disebabkan bahwa faktor fisik dianggap telah terwakili pada saat mata pelajaran praktik sehingga kondisi fisik secara otomatis meningkat. Anggapan tersebut kurang benar, karena tolak peluru gaya obrain memerlukan kondisi fisik tersendiri sehingga membutuhkan pembinaan fisik yang lebih baik.

Olah raga atletik merupakan olahraga yang mudah untuk dilakukan bila dilihat dari segi pelaksanaannya, akan tetapi menolak peluru seberat $7.26 \mathrm{~kg}$ untuk atlet putri dan $5 \mathrm{~kg}$ untuk atlet putri tentunya memerlukan pekerjaan yang menuntut banyak tenaga dan penguasaan teknik yang baik untuk mendapatkan prestasi yang baik. Karena yang menjadi ukuran dalam tolak peluru adalah jauhnya dari tolakan tersebut. Teknik tolak peluru gaya O'Brien atau gaya punggung ini pernah merupakan contoh bagi semua variasi teknik lain dalam tolak peluru modern. Bahkan sampai sekarang teknik gaya O’Brien ini masih dipakai dari semua teknik yang digunakan oleh seorang atlet yang berprestasi baiktingkat Nasional maupun Internasional dan juga diajarkan juga di sekolah sekolah maupun di perkumpulan-perkumpulan atletik yang ada pada saat ini. Suatu prestasi itu tidak bias muncul begitu saja melainkan harus melalui perjalanan yang panjang, tentunya juga harus melalui latihan-latihan yang intensif maupun pembinaan yang terarah serta ditunjang oleh adanya fasilitas yang sesuai dengan kebutuhan. Selain itu seorang atlet harus mempunyai tekad dan semangat yang tinggi untuk mencapai prestasi tingkat juara.

Tolak peluru gaya O'Brien adalah salah satu nomor yang terdapat pada nomor dalam cabang olah raga atletik yang sangat penting (mendasar). Tolak peluru gaya O'Brien merupakan teknik dasar yang sulit dipelajari, lebih-lebih untuk siswa yang belum terampil. Agar Tolak peluru gaya O'Brien dapat dilakukan dengan baik, terlebih dahulu perlu dikaji faktor-faktor yang mempengaruhi hasil Tolak peluru gaya O’Brien perlu ditelusuri factor penyebabnya. Dimana faktor-faktor yang mempengaruhi Tolak peluru gaya O’Brien diperlukan unsur-unsur kondisi fisik seperti: kekuatan, kecepatan, kelenturan, keseimbangan, ketepatan, dayatahan, kelincahan, dan koordinasi. 


\section{Hubungan Antara Kekuatan Otot Tungkai, Kekuatan Otot Perut, Dan Koordinasi Mata Tangan Dengan Kemampuan Tolak Peluru Gaya O’brien Pada Siswa Putri Kelas XII SMK Tri Sakti Gemolong Tahun 2019 (Iwan Arya Kusunma)}

Perbedaan kemampuan terutama terjadi karena kualitas fisik yang berbeda Endro Puji Purwono,dalam bahan ajar pertumbuhan dan perkembangan peserta didik(2011:84). Begitu juga dengan indeks massa tubuh yang mempengaruhi keterampilan atlet. Dengan demikian dapat dikatakan kondisi fisik yang baik adalah suatu persyaratan dalam usaha mencapai prestasi maksimal bagi seseorang dalam latihan Tolak peluru gaya O'Brien. Kondisi fisik yang ada pada pelempar harus menjadi pertimbangan sebagai suatu faktor yang menentukan dalam Tolak peluru gaya O'Brien yang sesuai dengan karakter dari masing-masing pelompat sehingga bias mencapai hasil latihan yang optimal sesuai dengan potensi yang dimiliki.

\section{B. METODE PENELITIAN}

Metode penelitian yang digunakan adalah metode deskriptif studi korelasional. Dalam hal ini Ali Maksum (2012:68) berpendapat bahwa "Melalui korelasional dapat diketahui apakah satu variabel berasosiasi dengan variabel yang lain. Hubungan antara variabel ditentukan dengan menggunakan koefisien yang dihitung dengan teknik analisis statistik hubungan antara variabel ditentukan dengan menggunakan koefisien yang di hitung dengan stgatistik analisis statistik" Penelitian ini untuk mengetahui hubungan antara kekuatan otot tungkai, kekuatan otot perut, koordinasi mata tanganterhadapKemampuan Tolak peluru gaya O’Brien.

\section{HASIL PENELITIAN}

\section{1) Deskripsi Data}

Data yang diperoleh dari tiap-tiap variabel tersebut kemudian dikelompokkan dan dianalisis dengan statistik, seperti terlihat pada lampiran. Adapun rangkuman deskripsi data secara keseluruhan akan disajikan sebagai berikut: 
Hubungan Antara Kekuatan Otot Tungkai, Kekuatan Otot Perut, Dan Koordinasi Mata Tangan Dengan Kemampuan Tolak Peluru Gaya O’brien Pada Siswa Putri Kelas XII SMK Tri Sakti Gemolong Tahun 2019 (Iwan Arya Kusunma)

Tabel 2.Deskripsi Data Hasil Tes Kekuatan Otot Tungkai , Kekuatan Otot Perut dan Koordinasi Mata Tangan dan Tolak Peluru Gaya O’brien .

\begin{tabular}{|c|c|c|c|c|c|c|}
\hline Variabel & Tes & $\mathrm{N}$ & Mean & SD & $\begin{array}{c}\text { Nilai } \\
\text { Tertinggi }\end{array}$ & $\begin{array}{c}\text { Nilai } \\
\text { Terendah }\end{array}$ \\
\hline $\begin{array}{c}\text { Kekuatan Otot } \\
\text { Tungkai }\end{array}$ & Test & 30 & 34.83 & 10.82 & 63 & 20 \\
\cline { 2 - 7 } & Re-test & 30 & 37.07 & 8.38 & 54 & 23 \\
\hline $\begin{array}{c}\text { Kekuatan Otot } \\
\text { Perut }\end{array}$ & Test & 30 & 15.20 & 2.02 & 20 & 11 \\
\cline { 2 - 7 } & Re-test & 30 & 15.77 & 1.91 & 20 & 11 \\
\hline $\begin{array}{c}\text { Koordinasi Mata } \\
\text { Tangan }\end{array}$ & Test & 30 & 10.67 & 2.04 & 17 & 8 \\
\cline { 2 - 7 } & Re-test & 30 & 11.97 & 1.73 & 17 & 9 \\
\hline $\begin{array}{c}\text { Tolak Peluru } \\
\text { Gaya O'brien }\end{array}$ & Test & 30 & 4.56 & 1.16 & 7.59 & 2.82 \\
\cline { 2 - 7 } & Re-test & 30 & 4.57 & 1.16 & 7.60 & 2.81 \\
\hline
\end{tabular}

\section{2) Uji Reliabilitas}

Uji reliabilitas bertujuan untuk mengetahui tingkat keajegan hasil tes masing-masing variabel yang dilakukan dalam penelitian. Hasil uji reliabilitas tes dan re-testKekuatan Otot Tungkai , Kekuatan Otot Perut dan Koordinasi Mata Tangan dan Tolak Peluru Gaya O'brien kemudian dikategorikan, dengan menggunakan pedoman tabel koefisien korelasi dari Book Walter yang dikutip Mulyono BiyaktoAtmojo (2008:22), yaitu:

Tabel 3. Range Kategori Reliabilitas

\begin{tabular}{|c|c|}
\hline Kategori & Reliabilitas \\
\hline Tinggi Sekali & $0,90-1,00$ \\
\hline Tinggi & $0,80-0,89$ \\
\hline Cukup & $0,60-0,79$ \\
\hline Kurang & $0,40-0,59$ \\
\hline Tidak Signifikan & $0,00-0,39$ \\
\hline
\end{tabular}


Hubungan Antara Kekuatan Otot Tungkai, Kekuatan Otot Perut, Dan Koordinasi Mata Tangan Dengan Kemampuan Tolak Peluru Gaya O'brien Pada Siswa Putri Kelas XII SMK Tri Sakti Gemolong Tahun 2019 (Iwan Arya Kusunma)

Hasil uji reliabilitas data Kekuatan Otot Tungkai, Kekuatan Otot Perut dan Koordinasi Mata Tangan dan Tolak Peluru Gaya O’brien pada penelitian ini adalah:

Tabel 4. Ringkasan Hasil Uji Reliabilitas Data

\begin{tabular}{|l|c|c|}
\hline \multicolumn{1}{|c|}{ Variabel } & Reliabilita & Kategori \\
\hline Kekuatan Otot Tungkai & 0.936 & Tinggi Sekali \\
\hline Kekuatan Otot Perut & 0.942 & Tinggi Sekali \\
\hline Koordinasi Mata Tangan & 0.885 & Tinggi Sekali \\
\hline Tolak Peluru Gaya O'brien & 1.000 & Tinggi Sekali \\
\hline
\end{tabular}

\section{3) Pengujian Persyaratan Analisis}

Sebelum analisis data dilakukan uji persyaratan analisis. Untuk analisis regresi diperlukan uji persyaratan analisis yaitu normalitas penyebarannilai dan persyaratan linieritas hubungan antara prediktor dengan kriterium. Hasil pengujian persyaratan analisis pada penelitian ini adalah sebagai berikut:

\section{Uji Normalitas}

Uji normalitas data dalam penelitian ini menggunakan chi-kuadrat. Adapun hasil uji normalitas yang dilKoordinasi Mata Tangan kan pada hasil tes Kekuatan Otot Tungkai $\left(\mathrm{X}_{1}\right)$, Kekuatan Otot Perut $\left(\mathrm{X}_{2}\right)$, Koordinasi Mata Tangan $\left(\mathrm{X}_{3}\right)$ dan Tolak Peluru Gaya O'brien (Y) pada penelitian ini adalah:

Tabel 5. Rangkuman Hasil Uji Normalitas Data

\begin{tabular}{|l|c|c|c|c|c|c|}
\hline \multicolumn{1}{|c|}{ Variabel } & $\mathrm{Db}$ & $\mathrm{M}$ & $\mathrm{SD}$ & $\chi_{\text {hitung }}^{2}$ & $\chi_{\text {tabel 5\% }}^{2}$ & Simpulan \\
\hline $\begin{array}{l}\text { Kekuatan } \\
\text { Otot Tungkai }\end{array}$ & $6-1=5$ & 47,64 & 4,98 & 2,578 & 11,070 & $\begin{array}{c}\text { Berdistribusi } \\
\text { normal }\end{array}$ \\
\hline $\begin{array}{l}\text { Kekuatan } \\
\text { Otot Perut }\end{array}$ & $6-1=5$ & 38,93 & 5,18 & 2,578 & 11,070 & $\begin{array}{c}\text { Berdistribusi } \\
\text { normal }\end{array}$ \\
\hline $\begin{array}{l}\text { Koordinasi } \\
\text { Mata Tangan }\end{array}$ & $6-1=5$ & 29,77 & 3,30 & 1,667 & 11,070 & $\begin{array}{c}\text { Berdistribusi } \\
\text { normal }\end{array}$ \\
\hline $\begin{array}{l}\text { Tolak Peluru } \\
\text { Gaya O'brien }\end{array}$ & $6-1=5$ & 4,24 & 0,70 & 2,167 & 11,070 & $\begin{array}{c}\text { Berdistribusi } \\
\text { normal }\end{array}$ \\
\hline
\end{tabular}


Dari hasil uji normalitas yang dilakukan pada tiap-tiap variabel tersebut dapat diketahui bahwa nilai $c h i$-kuadrat yang diperoleh $\left(\chi^{2}\right.$ hitung $)$ pada variabel Kekuatan Otot Tungkai $\left(\mathrm{X}_{1}\right)$, Kekuatan Otot Perut $\left(\mathrm{X}_{2}\right)$, Koordinasi Mata Tangan $\left(\mathrm{X}_{3}\right)$ dan Tolak Peluru Gaya O'brien (Y) lebih kecil dari nilai chi-kuadrat dalam tabel $\left(\chi_{\text {tabel } 5 \%}^{2}\right)$. Dengan demikian hipotesis nol diterima. Yang berarti bahwa data hasil tes Kekuatan Otot Tungkai $\left(\mathrm{X}_{1}\right)$, Kekuatan Otot Perut $\left(\mathrm{X}_{2}\right)$, Koordinasi Mata Tangan $\left(\mathrm{X}_{3}\right)$ dan Tolak Peluru Gaya O’brien (Y) termasuk berdistribusi normal.

\section{Uji Linieritas}

Uji linieritas hubungan antara masing-masing prediktor yaitu Kekuatan Otot Tungkai $\left(\mathrm{X}_{1}\right)$, Kekuatan Otot Perut $\left(\mathrm{X}_{2}\right)$, Koordinasi Mata Tangan $\left(\mathrm{X}_{3}\right)$, dengan kriterium yaitu Tolak Peluru Gaya O’brien (Y) dilakukan dengan analisis varians. Rangkuman hasil uji linieritas tersebut dapat dilihat dalam tabel sebagai berikut:

Tabel 6. Rangkuman Hasil Analisis Varians Untuk Uji Linieritas Hubungan Antara Prediktor dengan Kriterium

\begin{tabular}{|c|c|c|c|c|}
\hline Variabel & $\mathrm{Db}$ & $\mathrm{F}_{\text {hitung }}$ & $\mathrm{F}_{\text {tabel5\% }}$ & Simpulan \\
\hline $\mathrm{X}_{1} \mathrm{Y}$ & $4: 24$ & 0.17 & 2,78 & Model linier diterima \\
\hline $\mathrm{X}_{2} \mathrm{Y}$ & $13: 15$ & 0.31 & 2,43 & Model linier diterima \\
\hline $\mathrm{X}_{3} \mathrm{Y}$ & $20: 8$ & 0.67 & 3,15 & Model linier diterima \\
\hline
\end{tabular}

Dari rangkuman hasil uji linieritas tersebut dapat diketahui bahwa nilai $F_{\text {hitung }}$ linieritas yang diperoleh dari tiap variabel lebih kecil dari harga $\mathrm{F}_{\text {tabel }}$ 5\%. Dengan demikian hipotesis nol linieritas ketiga variabel tersebut diterima. Berarti bahwa baik korelasi antara $\mathrm{X}_{1} \mathrm{Y}, \mathrm{X}_{2} \mathrm{Y}$ dan $\mathrm{X}_{3} \mathrm{Y}$ berbentuk linier. 


\section{4) Hasil Analisis Data}

Hasil analisis korelasi dan analisis regresi antara data tes Kekuatan Otot Tungkai $\left(\mathrm{X}_{1}\right)$, Kekuatan Otot Perut $\left(\mathrm{X}_{2}\right)$, Koordinasi Mata Tangan $\left(\mathrm{X}_{3}\right)$ dengan Tolak Peluru Gaya O’brien (Y) penelitian ini adalah:

\section{Analisis Korelasi Tiap Prediktor}

Hasil analisis korelasi masing-masing prediktor dengan kriterium penelitian ini adalah sebagai berikut:

a. Berdasarkan analisis korelasi antara Kekuatan Otot Tungkai $\left(\mathrm{X}_{1}\right)$ dengan Tolak Peluru Gaya O’brien (Y), diperoleh koefisien korelasi sebesar 0.411 . Dengan $\mathrm{N}=30$, nilai $\mathrm{r}_{\text {tabel }} \%=0,361$. Ternyata $\mathrm{r}_{\text {hitung }}=0.411>$ $\mathrm{r}_{\text {tabel }} \%=0,361$. Hal ini menunjukkan bahwa terdapat hubungan yang signifikan antara Kekuatan Otot Tungkai $\left(\mathrm{X}_{1}\right)$ dengan Tolak Peluru Gaya O’brien (Y).

b. Berdasarkan analisis korelasi antara Kekuatan Otot Perut $\left(\mathrm{X}_{2}\right)$ dengan Tolak Peluru Gaya O’brien (Y), diperoleh koefisien korelasi sebesar 0.433 . Dengan $\mathrm{N}=30$, nilai $\mathrm{r}_{\text {tabel }} \%=0,361$. Ternyata $\mathrm{r}_{\text {hitung }}=0.433>$ $\mathrm{r}_{\text {tabel }} \%=0,361$. Hal ini menunjukkan bahwa terdapat hubungan yang signifikan antara Kekuatan Otot Perut $\left(\mathrm{X}_{2}\right)$ dengan Tolak Peluru Gaya O’brien (Y).

c. Berdasarkan analisis korelasi antara Koordinasi Mata Tangan $\left(\mathrm{X}_{3}\right)$ dengan Tolak Peluru Gaya O’brien (Y), diperoleh koefisien korelasi sebesar 0.480 . Dengan $\mathrm{N}=30$, nilai $\mathrm{r}_{\text {tabel }} \%=0,361$. Ternyata $\mathrm{r}_{\text {hitung }}=$ $0.480<\mathrm{r}_{\text {tabel }} \%=0,361$. Hal ini menunjukkan bahwa terdapat hubungan yang signifikan antara Koordinasi Mata Tangan $\left(\mathrm{X}_{3}\right)$ dengan Tolak Peluru Gaya O’brien (Y).

Ringkasan hasil analisis korelasi masing-masing prediktor dengan kriterium penelitian ini adalah sebagai berikut: 
Hubungan Antara Kekuatan Otot Tungkai, Kekuatan Otot Perut, Dan Koordinasi Mata Tangan Dengan Kemampuan Tolak Peluru Gaya O'brien Pada Siswa Putri Kelas XII SMK Tri Sakti Gemolong Tahun 2019 (Iwan Arya Kusunma)

Tabel 7. Rangkuman Hasil Analisis Korelasi Tiap Prediktor dengan Kriterium

\begin{tabular}{|c|c|c|c|}
\hline Variabel & $\mathrm{r}_{\text {hitung }}$ & $\mathrm{r}_{\text {tabel }}$ & Simpulan \\
\hline $\mathrm{X}_{1} \mathrm{Y}$ & 0.411 & 0,361 & Korelasi signifikan \\
\hline $\mathrm{X}_{2} \mathrm{Y}$ & 0.433 & 0,361 & Korelasi signifikan \\
\hline $\mathrm{X}_{3} \mathrm{Y}$ & 0.480 & 0,361 & Korelasi signifikan \\
\hline
\end{tabular}

\section{Analisis Regresi}

Analisis regresi yang dilakukan pada penelitian ini menggunakan analisis regresi ganda tiga prediktor. Hasil analisis regresi antara data tes Koordinasi Mata Tangan $\left(\mathrm{X}_{1}\right)$, Kekuatan Otot Tungkai $\left(\mathrm{X}_{2}\right)$, Kekuatan Otot Perut $\left(\mathrm{X}_{3}\right)$ Koordinasi Mata Tangan dengan Tolak Peluru Gaya O’brien (Y) penelitian ini adalah sebagai berikut:

1. Persamaan garis regresinya adalah:

$$
\hat{\mathrm{y}}=0.011 \mathrm{X}_{1}+0.205 \mathrm{X}_{2}+0.070 \mathrm{X}_{3}+0.326
$$

2. Koefisien korelasi dan determinasi antara prediktor dan kriterium:

$$
\begin{aligned}
& \mathrm{R}_{\mathrm{y}(1,2,3)}=0.673 \\
& \mathrm{R}_{\mathrm{y}(1,2,3)}^{2}=0.452
\end{aligned}
$$

3. Uji signifikansi analisis regresi.

Hasil uji signifikansi regresi penelitian ini dapat dilihat pada tabel berikut :

Tabel 8. Ringkasan Hasil Analisis Regresi

\begin{tabular}{|c|c|c|c|c|}
\hline Sumber Variasi & Db & JK & \multicolumn{1}{|c|}{ RK } & Freg \\
\hline Regresi (reg) & 3 & 17.7230 & 5.9077 & 7.1768 \\
\hline Residu (res) & 26 & 21.4022 & 0.8232 & - \\
\hline Total & 29 & 39.1252 & - & - \\
\hline
\end{tabular}

Dari hasil analisis regresi tersebut dapat disimpulkan, dengan $\mathrm{db}=\mathrm{m}$ lawan $\mathrm{N}-\mathrm{m}-1=3$ lawan 26, harga $\mathrm{F}_{\text {tabel }}$ 5\% adalah 2,89. Sedangkan nilai $\mathrm{F}$ yang diperoleh adalah 7.1768, ternyata lebih besar dari angka batas penolakan hipotesa nol. Dengan demikian hipotesa nol ditolak, yang berarti bahwa 
Hubungan Antara Kekuatan Otot Tungkai, Kekuatan Otot Perut, Dan Koordinasi Mata Tangan Dengan Kemampuan Tolak Peluru Gaya O’brien Pada Siswa Putri Kelas XII SMK Tri Sakti Gemolong Tahun 2019 (Iwan Arya Kusunma)

terdapat hubungan yang signifikan antara Kekuatan Otot Tungkai $\left(\mathrm{X}_{1}\right)$, Kekuatan Otot Perut $\left(\mathrm{X}_{2}\right)$, Koordinasi Mata Tangan $\left(\mathrm{X}_{3}\right)$ dengan Tolak Peluru Gaya O'brien (Y). Adapun besarnya nilai $\mathrm{R}^{2}$ antara Kekuatan Otot Tungkai $\left(\mathrm{X}_{1}\right)$, Kekuatan Otot Perut $\left(\mathrm{X}_{2}\right)$, Koordinasi Mata Tangan $\left(\mathrm{X}_{3}\right)$ dengan Tolak Peluru Gaya O’brien (Y) adalah 0.452.

\section{5) Pengujian Hipotesis dan Pembahasan}

1. Hubungan Antara Kekuatan Otot Tungkai dengan Tolak Peluru Gaya O'brien

Dari hasil analisis korelasi pada dataKekuatan Otot Tungkai dengan Tolak Peluru Gaya O’brien, diperoleh nilai r sebesar 0.411, dimana nilai tersebut lebih besar dari nilai $r_{\text {tabel }}$ pada taraf signifikansi $5 \%$ yaitu 0,361 . Karena nilai $r_{\text {hitung }}>r_{\text {tabel }}$, maka nilai korelasi signifikan. Hal ini berarti bahwaperubahan variansi Tolak Peluru Gaya O'brien dipengaruhi oleh komponen variansi Kekuatan Otot Tungkai.

2. Hubungan Antara Kekuatan Otot Perut dengan Tolak Peluru Gaya O'brien

Berdasarkan hasil analisis yang telah dilakukan terhadap data Kekuatan Otot Perut terhadap Tolak Peluru Gaya O'brien, diperoleh nilai $r$ sebesar 0.433, dimana nilai tersebut lebih besar dari nilai $r_{\text {tabel }}$ pada taraf signifikansi $5 \%$ yaitu 0,361 . Karenanilai $r_{\text {hitung }}>r_{\text {tabel }}$, maka nilai korelasi signifikan. Hal ini berarti bahwa variansi unsur Kekuatan Otot Perut berpengaruh terhadap peningkatan variansi Tolak Peluru Gaya O’brien.

\section{Hubungan AntaraKoordinasi Mata Tangan dengan Tolak Peluru Gaya} O'brien

Berdasarkan hasil analisis yang telah dilakukan terhadap data Koordinasi Mata Tangan terhadap Tolak Peluru Gaya O’brien, diperoleh nilai r sebesar 0.480, dimana nilai tersebut lebih besar dari nilai $r_{\text {tabel }}$ pada taraf signifikansi $5 \%$ yaitu 0,361 . Karenanilai $r_{\text {hitung }}>r_{\text {tabel }}$, maka nilai korelasi signifikan. Dengan demikian dapat disimpulkan bahwa Koordinasi Mata 
Hubungan Antara Kekuatan Otot Tungkai, Kekuatan Otot Perut, Dan

Koordinasi Mata Tangan Dengan Kemampuan Tolak Peluru Gaya O’brien

Pada Siswa Putri Kelas XII SMK Tri Sakti Gemolong Tahun 2019 (Iwan

Arya Kusunma)

Tangan memiliki hubungan yang signifikan terhadap Tolak Peluru Gaya

O’brien .

\section{Hubungan Kekuatan Otot Tungkai, Kekuatan Otot Perut dan} Koordinasi Mata Tangan dengan Tolak Peluru Gaya O'brien

Pada Hipotesis dinyatakan bahwa hubungan antara Kekuatan Otot Tungkai , Kekuatan Otot Perut dan Koordinasi Mata Tangan dengan Tolak Peluru Gaya O'brien di ketahui $\mathrm{R}_{\mathrm{y}(123)}^{2}=0.452$ sedangkan $\mathrm{r}_{\text {tabel }}$ pada taraf signifikasi 0,05 dan $n=30$ di dapat $r_{\text {tabel }}=0,361$, dengan hasil tersebut $r_{\text {hitung }}>$

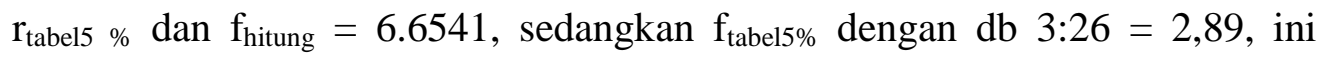
berarti $\mathrm{F}_{0}>\mathrm{F}_{\text {tabel5\% }}$ Maka hipotesis di terima.

\section{SIMPULAN}

Berdasarkan analisis data yang telah dilakukan dan pembahasan yang telah diungkapkan, diperoleh simpulan bahwa:

1. Ada hubungan yang signifikanantara Kekuatan Otot TungkaiDengan Tolak Peluru Gaya O’brien Pada Siswa SMK Trisakti Gemolong Tahun 2019, $\mathrm{r}_{\text {hitung }}$ $=0.411>\mathrm{r}_{\text {tabel }} 5 \%=0,361$.

2. Ada hubungan yang signifikan antara Kekuatan Otot Perut Dengan Tolak Peluru Gaya O’brien Pada Siswa SMK Trisakti Gemolong Tahun 2019, $\mathrm{r}_{\text {hitung }}$ $=0.433>\mathrm{r}_{\text {tabel }} \%=0,361$.

3. Ada hubungan yang signifikan antara Koordinasi Mata Tangan Dengan Tolak Peluru Gaya O’brien Pada Siswa SMK Trisakti Gemong Tahun 2019 r tabel, $\mathrm{r}_{\text {hitung }}=0.480>\mathrm{r}_{\text {tabel }} \%=0,361$.

4. Ada hubungan yang signifikan antara Kekuatan Otot Tungkai, Kekuatan Otot Perut dan Koordinasi Mata Tangan Dengan Tolak Peluru Gaya O’brien Pada Siswa SMK Trisakti Gemolong Tahun 2019, $\mathrm{R}_{\mathrm{y}(123)}^{2}$ sebesar $0.452>\mathrm{r}_{\text {tabel5 } \%}$ pada taraf signifikansi $5 \%$ sebesar 0.361 dan $\mathrm{F}_{0}$ sebesar $6.6541>\mathrm{f}_{\text {tabel }}$ pada taraf signifikansi $5 \%$ sebesar 2,89 . 
Hubungan Antara Kekuatan Otot Tungkai, Kekuatan Otot Perut, Dan

Koordinasi Mata Tangan Dengan Kemampuan Tolak Peluru Gaya O'brien

Pada Siswa Putri Kelas XII SMK Tri Sakti Gemolong Tahun 2019 (Iwan

Arya Kusunma)

\section{DAFTAR PUSTAKA}

Aip Syarifuddin 1997. Pengetahuan Olahraga.Jakarta: Cv Baru.

Ballesteros, J.M. 1980. Pedoman Latihan Olahraga. Jakarta: Cv Baru.

Bompa, Tudor, O. 1994. Power Training For Sport: Plyometrics For Maximum Power Development. Ontario: Mosaic Press.dendusnadi. blogsport. com/ 2010/11/shortput.tolak peluru.html.(akses 10/03/2013)

InternationalAssociation of Athletics Federations. 2000. Jumping Events Texs Book. Development Program IAAF PM.

Ismaryati. 2008. Tes dan Pengukuran Olahraga. Cetakan 2. Surakarta: LPP UNS dan UNS Press.

Persatuan Atletik Seluruh Indonesia.1996. PengenalanKepadaTeoriPelatihan. Jakarta. 